\title{
8 Tradition, gender, and empowerment
}

\section{The Birth of Theotokos Society in Helsinki, Finland}

\section{Pekka Metso, Nina Maskulin, and Teuvo Laitila}

The Birth of Theotokos Society (Jumalansynnyttäjän syntymän ybteisö in Finnish, henceforth the Society) is a lay-dominated Orthodox monastic community in Helsinki, the capital of Finland. It represents one of the ways in which monastics and laypeople alike can pursue an urban Orthodox way of life. The Society is led by a nun, Mother Elisabet. It welcomes both laywomen and laymen. At present, however, most active members are women. In this chapter, we study the Society from a gender perspective. First, we discuss how the Society is constructed by its members' relationships and activities. Second, we examine how the Society interacts with the Helsinki Orthodox parish, its clergy, and other employees, observing how this interaction also shapes and characterizes the Society. Last, we describe the material and immaterial dimensions of member engagement with the Society and investigate how these dimensions contribute to the Society's role in their lives.

Finland has been dominated by the Evangelical Lutheran Church since the sixteenth-century Protestant Reformation. Today, some 70 percent of the Finnish population (of c. 5.5 million) is Lutheran, while the Orthodox are a small minority of 1.1 percent. ${ }^{1}$ Orthodox monasteries were first established in Karelia-in the borderland between Finland and Russia-in the fourteenth century and in Pechenga (Petsamo in Finnish) on the Kola Peninsula in the sixteenth century. In 1944, Finland ceded most of its Karelian territories and Pechenga to the Soviet Union. The three monasteries and one convent located in these areas were evacuated and resettled in Heinävesi, a rural municipality 400 kilometers north-east of Helsinki. At the time of the evacuation, Orthodox monasticism was unknown in Finland outside of Finnish Karelia. More than 70 years later, Valaam (Valamo in Finnish) Monastery and Lintula Convent continue to host a small community of monks and nuns, invite laypeople as guests for short periods, especially during holiday seasons and Great Feasts, and promote Orthodox monastic tradition and prayer life in present-day Finnish society.

Not foreign to Orthodoxy, lay-dominated monastic societies are atypical in the Finnish religious landscape. Presently, there are three such societies, all located in the diocese of Helsinki in southern Finland. The Juliana 


\section{Pekka Metso et al.}

Orthodox Women's Association, founded in 1997, targets women who have experienced some radical change in their life, supporting their everyday Orthodox lifestyle. The lay monastic Panagia Society, established in 2013, invites both men and women to pursue ascetic life according to the Athonite monastic tradition. The Juliana Association is located in a small, quiet town and the Panagia Society in a remote village, both some 140 kilometers north of Helsinki.

The third lay-dominated monastic institution, the Birth of Theotokos Society, operates in the heart of Helsinki, promoting a traditional Eastern Orthodox monastic lifestyle in the form of prayer, common worship, activities, and spiritual direction. Moreover, the Society is actively connected with the liturgical life of the Helsinki parish. The publicly available information on services, the Society's visibility in local and national media, and the lack of exclusive structures such as a membership register or fee, all enable anyone to visit the Society's chapel for help or prayer. Its organization and location in the city center make the Society different from that of the other Finnish Orthodox ascetic and monastic institutions.

The idea to establish the Society first arose in 2006, when Mother Elisabet was not yet ordained as a nun. It started to materialize six years later, when the (since retired) Metropolitan of Helsinki, Ambrosius, appointed her the head of the Birth of Theotokos Society, then located on the outskirts of Helsinki. Despite her ordination and monastic duties, Mother Elisabet kept her civilian profession as a high-ranking state official and medical doctor until her retirement in 2018. The other founding member of the Society, a monk, moved to the Valaam Monastery in 2013. The same year, the Society moved to an apartment owned by Mother Elisabet in central Helsinki. The area is near the main railway station and can be restless due to illegal drug trade and prostitution. From 2014 onwards, the Society has rented a ground floor shop consecrated as a chapel in the same building.

This chapter is based primarily on ethnographic data, including interviews, participant observation, and research diaries. ${ }^{2}$ The interviewees were selected by Mother Elisabet, who has a good knowledge of research ethics due to her education as a medical doctor. Therefore, she suggested selecting members that she considered strong enough to go through a long and intimate interview that could potentially revive stressful memories. The interviews thus provide an active participants' perspective on the Society, but do not necessarily reflect the experiences of its most vulnerable members.

We interviewed six women between the ages of (approximately) 40 and 90. At the time of the interviews, the women were single; some were single parents, either divorced or widowed. Their social status was middle class and, based on their work history, their education intermediate or higher. The interviews lasted between 100 and 180 minutes, and were recorded and transcribed for thematic analysis. Except for Mother Elisabet, we refer to our research participants using pseudonyms. 
All the interviewees had been members in the Evangelical Lutheran Church prior to joining the Finnish Orthodox Church in adulthood. Adult conversion to the Orthodox Church has become a common phenomenon in Finland in recent years, while membership in Christian denominations in general is declining (Nguyen 2007; Statistics Finland 2016). Converts with a Lutheran upbringing are currently prominent among the Orthodox faithful and clergy. Since men were only scarcely involved in the Society's activities, we did not interview any. Some men attend services at the chapel, occasionally call in to get advice, or visit out of curiosity. Parish priests regularly celebrate the Divine Liturgy. As studies of many churches have demonstrated, women are often more involved in church activities, whereas men occupy leading positions (Walter and Davies 1998; Trzebiatowska and Bruce 2012; Hovi 2014).

According to Mother Elisabet, the Society is, "for the most part," a community of "wounded people," of whom she distinguished four types. First, those who only participate in services in the chapel. Second, people going through some kind of tragedy: they come for an intensive period and then disappear. Third, people who visit the Society now and then, and, fourth, people who visit regularly. Mother Elisabet identified the people in the fourth category as individuals at the intersection of emotional, economic, and medical challenges. They are regularly involved in the chapel's weekly routines such as preparing refreshments, doing simple needlework, or making decorations for Great Feasts. Like many of the occasional visitors, they evidently find consolation in their dialogs with Mother Elisabet.

\section{Theoretical premises: theo-anthropology, agency, and empowerment}

We chose theological and sociological analysis to help us understand women's religiosity in the context of urban monastic and communal life. Our theological framework, focusing on the equal dignity of men and women and the status of women in monastic life, is compatible with our sociological framework of agency. In order to elaborate our approach, we first discuss Elisabeth Behr-Sigel's interpretations of theological tradition and history as contributing to the ministry of women. Second, we outline our understanding of how women's everyday religion can positively influence their agency and empowerment. In the analysis, we apply these two frameworks to explore the situated, temporal, and complex nature of our interlocutors' religiosity, as illustrated in their accounts.

A leading Orthodox theologian of the twentieth century, Elisabeth Behr-Sigel (1907-2005) contributed to the conceptualization of the ministry of women in the Orthodox Church (Behr-Sigel 1991; Behr-Sigel and Ware 1998). The twentieth-century Orthodox women's movement worked toward "breaking the silence" surrounding the tradition of excluding women from ministry. It aimed at abolishing the sinful hostility "between 


\section{Pekka Metso et al.}

a bad masculinity and a bad femininity," which has distorted the image of woman in the history of the church (Behr-Sigel 1991, 103-114). BehrSigel's Christian anthropology or theo-anthropology builds on a critical reading of the Bible and patristic theology. Her The Ministry of Women in the Church (originally published in French in 1987 as Le ministère de la femme dans l'Église) is her key work, and makes the following four main arguments:

First, Christian personalism overcomes the dichotomy of masculine and feminine. Building on patristic theology (e.g., the Cappadocian Fathers and John Chrysostom), Behr-Sigel (1991, 91-92, 117-119, 130-132) proposes that individuals (human persons) are concrete, uni-complex, composite human beings, with a socially accentuated, formed or deformed feminine or masculine dominance.

Second, women have experienced oppression in the church (Behr-Sigel 1991, 73-78, 122-123). In Behr-Sigel's reading, mainstream biblical exegesis is not based on genuine theological premises, but is supported by outdated cultural stereotypes and historical conditions, dualism, and fear of sexuality. The Bible and tradition propose reciprocal masculinity and femininity in the church. Furthermore, she maintains that, in contrast to the mainstream feminist interpretation of Christianity, Orthodox believers do not understand the true church as a "society with a patriarchal structure thought up by men and governed by and for them" (122-123).

Third, the whole of humanity should strive toward feminization. In the Orthodox view Theotokos, the Mother of God, is an archetypal image who defines the woman as a figure of love with a mission to remind the entire humanity of the importance of following "the law of love" and opening "oneself to the universal." Behr-Sigel (1991, 77-79, 130-134, quote from page 134) calls for the feminization of human beings by awakening and preserving in men and women alike a love-driven "feminine attitude of effacement and of acceptance."

Fourth, monastic communities may liberate women. Since Antiquity, Christian monasticism has affirmed women as genuine persons. Asceticism, as an alternative to marriage and motherhood, has had the potential to liberate women from many social restrictions. Following in the footsteps of early monastic communities, Behr-Sigel (1991, 118-122, quote from page 134) argues that new communities may be created as "places where being would have priority over having, where inner fulfillment would be more important than competing for power and where science and technology would serve life, not death.” According to Behr-Sigel, the Orthodox Christian way of life leads to a proper understanding of the human nature as an infinite totality of feminine and masculine potentialities. This vision can materialize in the life of a monastic community, and may be somehow "liberating" or empowering for its members.

Behr-Sigel's approach can be seen as compatible with the concept of agency in the sociology of religion and gender studies. In sociological research, 
agency is often defined as a person's intentional and conscious effort to achieve something. Successful agentic action often implies changes in power relations. Here, our focus is on microlevel manifestations of such relations. Thus, in the analysis, we trace the interviewees' experiences and interpretations of their status within the Society, the parish, and the Orthodox Church in general.

In previous research, the concept of empowerment has been understood to refer to increased autonomy: to women gaining more say in their own lives (see Ozorak 1996; Sadati et al. 2015). Like agency, empowerment is often considered in terms of its outcome. Here, we emphasize the processual aspects of empowerment by paying special attention to our interlocutors' accounts of interactions between Society members and their relations with the outside world, including priests and local parish structures (cf. Ammerman 2014, 212-249; Pollari 2017, 41-46).

Sociologist of religion Nancy Ammerman $(2014,2016)$ has stressed that scholars should be cautious not to narrow down what actually is a multitude of "everyday religion." According to her (Ammerman 2016; see also Emirbayer and Miche 1998; Leming 2007; Hovi 2014), laypeople's religious lives and experiences are complex, layered, and deeply rooted in the social and cultural context. This holds true for our interviewees' religious lives. The Society, as a community of monastics and lay participants, is constructed through interpersonal relations and material and immaterial realities both within and outside formal religious institutions. That is to say, it is the product of ongoing negotiations and interpretations, produced by laypeople and religious professionals in various everyday situations: individual and collective, private and public, and more or less official.

All in all, taking our cue from Ammerman, we understand agency here as oscillation between everyday practice and dynamic action, where both are related to a meaningful Orthodox religious life. We conceive of the Society members' empowerment as evolving through both the discursive and material aspects of their everyday religion (see Ammermann 2014, 2016). In the analysis, we therefore emphasize what the women do (activities); how they share experiences and talk about religion together (discourse); and what kinds of embodied relations, spaces, and objects are involved in their religious practice (materiality). This approach has previously been used to investigate the religiosity of Finnish women in general (Utriainen and Salmesvuori 2014) and elderly Finnish Orthodox women in particular (Kupari 2014, 2016).

Our interviewees described their individual religious practice, the Society's activities, and participation in parish life as equally significant. Nevertheless, their accounts reveal that the Society provided them with special tools to pursue an active and meaningful Orthodox life-thus contributing to their agency and empowerment in their daily lives and as lay members of the Finnish Orthodox Church. To better understand this, we now turn to the analysis of our ethnographic data. 


\section{Activities and communality}

When we are talking about the Society we speak of two different communities. So there is this monastic community that only I belong to at the moment.... And then there is this extended community, and it is very meaningful. Because they [members] can be served and are provided with certain possibilities, presence, and whatever they themselves look for.

Mother Elisabet is describing the difference between two parallel realities within the Society: the monastic life upstairs, with one nun (herself), and the chapel community downstairs, where people come to pray, socialize, and meet Mother Elisabet. She describes her ministry or service in the chapel community as "presence" through which people are encouraged to action in the form of simple spiritual practice and, ultimately, to gain spiritual agency.

In more conventional monasticism, members customarily participate in the community by carrying out various duties. Anneli, who had served in the Valaam Monastery as a guide and by waiting tables, constrasted the Society with Valaam, where assigned duties are central. In the Society, "none of us has fixed duties, it is very freely organized." Mother Elisabet said that this was because people usually visit the Society when they are sick or otherwise suffering. The daily running of the chapel does not, therefore, depend on members of the chapel community. Engagement with the Society is not constructed through spiritual labor but through voluntarily lending the community a helping hand. "If there is nobody else to take care of cleaning or do the dishes, I do it," said Mother Elisabet. Thus, one could claim that the Society is not a place for accomplishing duties, but rather a safe haven.

Daily services (morning prayers, matins, the Akathist Hymn, and intercessions) are celebrated at the Society's chapel from Monday to Saturday by Mother Elisabet or available members. The schedule is updated weekly on the Society's website and can be received by text to one's cellphone. According to Mother Elisabet, it is important to mediate the exact time of prayer for those who have asked for intercession. For the Saturday night vigil, Sunday morning Liturgy, and services during major feasts, the members attend their local churches. Mother Elisabet regularly leads Jesus Prayer services at Kotikirkko (Home Church), in the Helsinki parish main building. There are only two fixed days for Liturgy in the Society chapel: the Birth of the Mother of God on September 8 and the feast of St. Xenia of Petersburg on January 24. Occasionally, the Divine Liturgy is celebrated at the chapel by a visiting priest.

Prayer services structure monastic life and are the raison d'être of the Society. Several of our interlocutors emphasized the significance of continuous prayer. Anneli stated: "I really believe that praying has always worked miracles. If people truly pray, it helps." Helena had an idea of an endless 
chain of prayer that brings Christians together: "If you have no strength to pray yourself, there is always prayer somewhere. There is always a monastery or a time [for prayer] somewhere." Kyllikki, moreover, compared daily prayer to "rye bread," evoking the poetic meaning of rye as the ultimate nourishment in Finnish culture.

The Society's activities also have an economic dimension. Active members bake and deliver phosphoron, the Eucharistic bread, to churches, and operate a small-scale catering service for baptisms and other family celebrations. The chapel also has a small shop selling icons and books. Furthermore, the interviewees did everyday chores in the chapel, washing dishes after a post-service cup of coffee, cleaning, and doing handicrafts during the opening hours. As Mother Elisabet put it: "Here nothing is done without God being present. No matter how prosaic, nothing goes beyond His sphere of influence."

The hospitable atmosphere in the downstairs chapel emanates from the invisible monastic life upstairs. Anneli explained: "You can go there to speak about what concerns you, and she [mother Elisabet] always has time." During our fieldwork, Mother Elisabet could be contacted by paying a visit or by phone. On Thursdays, Fridays, and Saturdays, the chapel is kept open as a sitting room where guests and members can do needlework or knit, talk or just listen, have a cup of coffee, buy necessities for prayer life, or be comforted by Mother Elisabet in times of hardship.

The elementary Orthodox way of life begins with and is manifested in small actions, like making the sign of cross when starting a task. The purpose of the monastic community, according to Mother Elisabet, is to be present for guests visiting the Society chapel and give them guidance in such simple ways to lead a spiritual life:

Meeting the visitors' needs, to help them with their spiritual life. It does not necessarily mean the Liturgy or spiritual discussions. We have them too, but I mean that...it is the presence. When we are sitting together in the chapel with needlework. There is value in humdrum chores.

Participating in services and activities, praying, and simply being present constitute Orthodox life in the shared space of the chapel. The Society has an open structure, which provides laypeople with an opportunity to learn different practices and duties (liturgical, practical, and other), according to their abilities. This has much in common with Behr-Sigel's understanding of genuine Orthodox religiosity: tradition is the framework within which people truly live their religiosity. Or, paraphrasing Emmanuel Levinas (1974), the Society gives the interviewees the necessary basis of existence, which enables them to fulfill their own needs without neglecting those of others. Members' agency is manifested and supported through socialization and collective action. 


\section{The society in relation to the outside world}

The Society is embedded in the local Helsinki Orthodox parish and the Finnish Orthodox Church. In Orthodoxy, ritual life and institutional hierarchy are sex segregated. Society members had adapted to this gendered division of labor, while at the same making use of traditional patterns to pursue an active lay life acceptable by Orthodox standards.

In the interviews, a recurrent theme was what could be termed "mutual benefit." Mother Elisabet stressed the significance of laypeople for the parish. Helena, likewise, stated that "the parish cannot exist without laypeople." The other research participants described their relations with the parish through emphasizing their participation in church activities according to their abilities, competences, or talents: singing in the choir in the Divine Liturgy, making church decorations such as käspaikka, traditional Karelian embroidered needlework, or volunteering at Valaam or Lintula during the holidays. In general, our interlocutors' understanding of a quotidian Orthodox way of life involved serving both their parishes and their families, children, and grandchildren.

Helena held an administrative position in the Society and led Jesus Prayer services in the parish when needed. Marjatta had been singing for years in the church choir, and Johanna participated in panikhida memorial services for the deceased every other week when her ex-husband looked after the children. Most of the interviewees had served as board members in various parish organs. Through such forms of institutionalized involvement, they established themselves within the parish and the Orthodox Church as "indispensable" and therefore, also independent insiders. Immersion in the everyday running of the parish thus contributed to our research participants' sense of agency and empowerment.

Nevertheless, this independence was not pushed too far. A good example of Society members' tacit acknowledgment of traditional Orthodox authority is the Eucharist, at which only a priest may officiate. Mother Elisabet summarized the issue by emphasizing the priority of services in the parish churches over those conducted in the chapel. Overall, the Society and the parish were closely linked at the liturgical level, so the Society could not be dismissed as a dissenting sect. The Society's relationship with the parish is characterized by theological and social interaction; members keep to the confines of tradition in relation to it and the wider church.

The overlap between the Society and the parish (and church) indicates that one can live as a layperson and lead an Orthodox way of life in both. This was illustrated, for instance, by Johanna, who stated that the parish is important for her, but that she also participates in the Society's activities. According to our interlocutors, however, some important aspects of the Society were missing from the parish. Since the Society lacks traditional hierarchy, one can come and go as one pleases and participate freely as oneself. As Anneli put it, the Society is "a place of equals." Meetings with Mother Elisabeth took place in the Society chapel and not in the parish, so 
the Society is also constructed in opposition to it. For the interviewees, the Society had "added value" that the parish could not give.

Our interviewees compared the nature of the Society to Orthodox monasticism. They all had positive experiences of visits to a monastery or convent, which had deepened their understanding of the "angelic life." However, they did not see monastic life as an option for them at present. All of them had a solid understanding of the demands of monastic commitment and wanted to pursue lay cultural learning of the Orthodox way of life instead. Mother Elisabet, too, was convinced that supporting a Christian way of life rather than promoting monasticism is the Society's primary task. In her view, the Society is a place of rest and renewal for people living in the world. It guides people to sanctify everyday life by doing "little things, very little things." Mother Elisabet crystallized the meaning of the chapel as a spiritual space by calling it "the presence of monasticism in the middle of the city." The monasticism advocated by the Society is constructed around regular services that are promptly mediated, the articulated equality among members, and the lack of social control in participation. This kind of "easy" Orthodoxy encourages members' own initiative to act, thus empowering them.

Theologically, the Society can be seen as bringing together women with different roles, statuses, and backgrounds, and foster interaction not dominated by a predetermined paradigm or social expectations. Rather, as a community of monastic(s) and laywomen, it creates a space and existence that allows people to be themselves despite the restrictions of the hierarchy and the often rigid social norms of the Orthodox Church.

\section{The society as a physical and spiritual community}

Based on the interviews, the physical space of the chapel, where most of the Society's common activities take place, played a very important role in the religious lives of its members. The chapel is a place for presence and for theological discussions. It is a place that, as Johanna said, "creates true peace of mind" and, according to Helena, "the only place where anybody understands a word" of what she says. Society activities are experienced as equal, free of competition for social acceptance, and consoling. Marjatta pointed out that the Society consists of "likeminded peers." Johanna and her children felt "fully accepted" there. Helena and Anneli both deepened their prayer life in the chapel and felt "accepted" and "appreciated."

Overall, our interlocutors describe the Society as a supportive learning environment where different ways of conducting an Orthodox life are accepted. Hence, it is also seen as strengthening its members' faith. According to Mother Elisabet, people still advancing in their religiosity can develop their Orthodoxy there. Marjatta pointed out that one cannot take refuge solely in human beings, but in God; this can be interpreted to indicate that Society members help each other to get closer to God. For the elderly members in particular, Mother Elisabet also functions as a substitute for 
a confessor. Anneli emphasized: "I know that I have someone close to me, someone I can always lean on. It is of immense help." To paraphrase Mother Elisabet again, the Society is a community where people who need each other can rest together. The role of congenial relationships in personal and spiritual growth has also been acknowledged in identity theory (e.g., Deaux et al. 1999).

Mother Elisabet manages the Society's intercession list, which she prays through privately in the chapel daily after matins. The importance of common prayer for someone, either living or deceased, was acknowledged by our research participants. Kyllikki emphasized the value of remembering the dead, while Marjatta stated that "the fact that the others pray for me is even more significant." In other words, praying was conceived of as a gift that could be given or received, depending on circumstances. The idea of reciprocity was also expanded to cover material things such as donations. Marjatta explained that although she is not wealthy, she had presented an unspecified nun with a bike, "because she had such a bad bike," and had donated a sewing machine she did not need to a nunnery.

The Society is also linked to the communion of Orthodox saints. The Mother of God and other saints play an important role in the everyday lives of the members. In the physical space of the Society, the presence of and communion with saints is manifested through icons; most walls of the tiny chapel are covered with them. The interviewees also had several icons at home and even carried icons in their handbags. Icons served as companions in everyday strategic decisions, sources of guidance, and tokens for prayer.

The Society's web page emphasizes the active presence of saints in the life of the Society. Of all Orthodox saints, it gives prominence to St. Xenia of Saint Petersburg (d. c. 1803). According to ecclesiastical tradition, after her husband's death she distributed her wealth to the poor and begun to live like a nun dressed in her husband's clothes. Mother Elisabet identified a specific spiritual connection between St. Xenia's vita (life) and her own pursuit of ascetic life in the middle of the city, where she was constantly mistaken for and mocked as a Muslim woman because of her nun's habit: "Above anyone else, she [St. Xenia] understands challenges, and helps me to find answers as well." Helena and Johanna maintained that St. Xenia had helped them to find housing.

The interviewees emphasized their everyday interactions with saints. Helena said, "they had the same fears and doubts as we do." Saints' lives were seen as patterned along similar lines to the lives of the interviewees. In some cases, the relationship with a saint could even be characterized as constant "cooperation," which helped the interlocutor in question to face the complexities of postmodern Finnish society. Asking for and receiving practical help from particular saints strengthened the everyday and this-worldcentered model of living Orthodoxy advocated by the Society. Our research participants' dialog and engagement with saints can be understood as an important feature of their religious agency. 
As the Society's patron, the most important saint for members was the Mother of God. Mother Elisabet characterized the Mother of God as a courageous teenager who got pregnant outside wedlock, married an old widow, and bore the social consequences of her choices. Later, she suffered immensely, having to face and witness the death of her child, but did not collapse. These aspects of the Virgin Mary's life, suffering and survival, recurred in the experiences of the interviewees and gave them some important clues as to how to lead an Orthodox life. Relatability and familiarity were crucial in other saints. If a saint's life made them appear difficult to approach or understand, Society members were unlikely to express daily devotion to them.

Mother Elisabet was the axial figure around which the Society turned, as both a physical and spiritual community. Her personality and actions aroused commitment among the interviewees. Johanna explained how she felt like "an invisible child" whom Mother Elisabet had made visible again through her attention and unconditional acceptance. ${ }^{3}$ An easily approachable person, Mother Elisabet helped the interviewees and other people in spiritual matters and everyday problems. Helena even considered Mother Elisabet as almost like a starica, a female monastic elder advisor and teacher. As a woman, she is a peer and equal to the (female) members, but as a nun, she is acknowledged to have authority reminiscent of that of a priest or monk. Mother Elisabet herself compared the women's discussions with her to talking to a priest or confession, with the exception that her gender helps women to approach her. Women may sometimes find it difficult to discuss their concerns with male confessors.

As a nun, Mother Elisabet is dedicated to being "dead to the world" and living the "angelic life." This frees her of the social restrictions on male clergy: "I do not need to be that polite, I can easily tell things straight... I can bluntly say what a goof someone has been when they have done something stupid." In other words, priests, who are prone to offering theological instructions and choosing their words carefully, may appear too ambivalent in their advice to laypeople. Mother Elisabet, in contrast, follows her own understanding of the monastic rule, which allows her to practice honesty and to treat others as equals. She is a role model for our interlocutors, educated and economically independent Finnish women who want to be active within a patriarchal ecclesiastical institution. Their activities, which are both traditional and (post)modern, challenge traditional Orthodox hierarchical structures. Marjatta gave an example of this when offering her interpretation of the Orthodox practice of asking for a blessing from a priest:

We position our hands [reference to the gesture of asking a blessing]. We go in front of the priest. We ourselves take the initiative [to show] that we want it [a blessing]... And the priest knows it, no need to say anything, and then he blesses... 


\section{Pekka Metso et al.}

Here, Marjatta describes the structured, traditional ritual of receiving blessing from a priest. For her, the layperson's initiative puts the act in motion and not the traditional liturgical setting in which everyone is expected to ask a blessing or the equally traditional authority of the priest, which "good" parishioners are expected to acknowledge through asking a blessing.

All in all, the material dimensions of the Society are focal for its significance to our research participants. In the chapel, social relations operate differently than in the outside world, and in relation to hierarchy, on a more equal basis. The chapel is a safe space for learning a religious lifestyle and expressing one's religiosity through prayer, worship, discourse, and confession. The person of Mother Elisabet is crucial to bringing these positive attributes to fruition.

Set within our theological framework, the Society is an ecclesiastical context and lived reality (more than a theological vision) constructed by its members themselves. It enables the interviewees to pose questions, share thoughts, work together, get spiritual guidance from another woman, and interact, to create and maintain the social and spiritual basis of the Society. Mother Elisabet is another reason for membership, particularly her special position somehow between the Society (as an autonomous place for its members) and the parish (where one is expected to behave similarly to the other parishioners). Precisely because Mother Elisabet is not a man, and thus cannot be a member of sacramental Orthodox clergy, she can be both honest and equal to other women. So her role in the Society challenges traditional Orthodox hierarchical structures, although none of the interviewees said so explicitly. In Weberian parlance, Mother Elisabet performs her pastoral role charismatically and with an intention to show that women, too, can be active within a traditional ecclesial institution.

\section{Conclusion}

The Birth of Theotokos Society in Helsinki promotes Eastern Orthodox monastic tradition in the heart of the Finnish capital in a postmodern, Northern European cultural and social context. Based on ethnographic material, we have shown how the Society is constructed through the activities, interactions, and meaning-making of its members. These processes are expressions of and supported by the agency of our interviewees, which empowered them both as (religious) women and as (lay) Orthodox.

The women's activities empowered them in three ways. First, intense commitment to the Society and involvement with its activities (e.g., prayer, discussion groups, voluntarily participation in communal chores) turned the Society into a kind of safe haven, where women can (or feel they can) themselves decide what they do, how, and when.

Second, the spiritually, socially, and personally empowering effects of the Society arise from its nature as a meeting place for likeminded women 
with similar religious aspirations to express and share their thoughts and experiences freely and equally.

Third, the interviewees acknowledged the leading, charismatic role of Mother Elisabet; they saw her as the Society's heart, holding it together. Her personality, example, dedication to serve, and pastoral ministry (listening, discussing, guiding, and receiving confessions) represented a fundamental model of true Orthodoxy to them, an alternative to the traditional malecentered understanding of their faith. Members did not exclusively participate in Society services and activities; they also did so in Helsinki Orthodox parish, which was important in constructing the Society and giving it meaning.

Agency can manifest in traditional behavior with a knowledge that, as Mother Elisabet said, "I do not have to do this, instead, I'm free to do this." As Marjatta said, tradition or society does not force one to ask the priest's blessing; she decides for herself whether or not to approach a priest. Independence originating from this kind of agency is important to our interviewees. They constructed their belonging based on a shared understanding that one can freely choose to take care of everyday chores and one's spiritual life in the Society.

Mother Elisabet stresses the importance of easy access to help. She is often approached to discuss issues that women find difficult to share with male clergy. As a supportive learning environment for religious life, the Society fosters a shared experience of equality and meaningfulness. It can be argued that, through participating in the Society's activities, members and guests enhanced their agency in their personal lives and in their parish despite social pressures and dominating structures. Mother Elisabet led this process by guiding others in the Orthodox way of life. This understanding of the Society as an education to Orthodoxy was also echoed in Mother Elisabet's rather pragmatic and simple thoughts regarding the Society's future. Her primary goal is simply to survive: as long as they can pay the rent, the Society exists. She hopes that in the future there will be more committed nuns, so that the chapel may stay open daily to welcome guests.

The Society was initially intended to have male and female members. Yet mostly women actively participate, share thoughts, work and interact together, and get spiritual guidance from a nun. This gender imbalance is acknowledged. Mother Elisabet stated that the Society was willing to offer responsibilities to men as well, but they had proven hard to reach. "Female dominance," as she put it, may scare men away from crossing the Society's threshold.

One more dimension requires attention, namely the Society's special status as a material entity. Several of the activities take place in a concrete place, the chapel. It is the locus where the women's agency evolves. It is really their space, where they can feel free and happy despite their imperfectness and express themselves unhindered by the expectations and prescriptions of a larger community, Orthodox or otherwise. The apartment belongs to Mother 


\section{Pekka Metso et al.}

Elisabet and the Society pays the rent of the chapel; the parish has no control over it. So the women quite literally stand on their own territory. In Victor Turner's terms, the chapel is an arena where the Society members live in a "permanent" liminal phase. They are simultaneously attached to Finnish and global Orthodoxy (a structure), and a communitas of equals allowing them to select and live up to those aspects of Orthodoxy that are most important in their present situation (cf. Turner 1969). This dialectic, realized in the Society's selective performance of tradition, empowers its members.

How do these findings suit our theological perspective, Elisabeth BehrSigel's ideals of balanced conception of human being, and freedom from male oppression in the Orthodox Church? To begin with, the Society is not explicitly dedicated to these aims. A conscious feminist agenda did not emerge in the data, and hostility between femininity and masculinity or the suppression of women in the church was rarely indicated by the interviewees. Thus, the Society's empowering effect was not based on its "feminine theology," but its "marginality." It is a borderline community. Based on the interviews, the Society offers a secure space (physically, mentally, and socially) for women to exist and act freely and reach their full potential. In promoting traditional Orthodox monasticism, the Society creates a modern (individual) way of practicing it, as Behr-Sigel envisioned.

\section{Notes}

1 The roots of Eastern Orthodoxy in Finland and the neighboring Karelia can be traced to contacts with Novgorod from the eleventh century. Administratively, the Karelian Orthodox were first part of the archbishopric of Novgorod, then the diocese of St. Petersburg. In 1809, Finland was annexed as a Grand Duchy to Russia and, in 1892, the Orthodox parishes of Finland and Finnish Karelia were united into a separate Orthodox diocese. After the Russian revolutions and Finnish independence in 1917, the diocese became an autonomous church in 1923 under the Patriarchate of Constantinople (see Laitila 2006).

2 The fieldwork was conducted in November-December 2017 (for interview dates, see references). The semi-structured interview form was composed jointly by the three authors. Nina Maskulin conducted the interviews (in Finnish) and produced their transliterations, and Pekka Metso was responsible for participant observation. All translations are by the authors.

3 The Invisible Child (1962) is a children's book classic by the Finnish author Tove Jansson. It is a story of a little girl, Ninny, who has become invisible after being mistreated by her caregiver. Moominmamma's affection and care make her reappear and find her place in the world.

\section{Interviews}

Anneli, December 1, 2017, Helsinki.

Helena, December 20, 2017, Helsinki.

Johanna, December 15, 2017, Helsinki.

Kyllikki, December 8, 2017, Helsinki. 
Marjatta, December 2, 2017, Helsinki.

Mother Elisabet, December 13, 2017, Helsinki.

\section{Bibliography}

Ammerman, Nancy. 2016. "Lived Religion as an Emerging Field: An Assessment of Its Contours and Frontiers." Nordic Journal of Religion and Society 29 (2): 83-99. doi:10.18261/issn.1890-7008-2016-02-01.

Ammerman, Nancy. 2014. Sacred Stories, Spiritual Tribes: Finding Religion in Everyday Life. Oxford: Oxford University Press.

Behr-Sigel, Elisabeth. 1991. The Ministry of Women in the Church. Translated by Steven Bigham. Redondo Beach: Oakwood Publications.

Behr-Sigel, Elisabeth, and Kallistos Ware. 1998. L'ordination de femmes dans l'Église orthodoxe. Paris: Cerf.

Deaux, Kay, Anne Reid, Kim Mizrahi, and Dave Cotting. 1999. Connecting the Personal to the Social: The Functions of Social Identification. Mahwah: Lawrence Erlbaum Associates.

Emirbayer, Mustafa, and Ann Mische. 1998. "What is Agency?” American Journal of Sociology 103 (4): 962-1023.

Hovi, Tuija. 2014. "Servants and Agents: Gender Roles in Neocharismatic Christianity." In Finnish Women Making Religion: Between Ancestors and Angels, edited by Terhi Utriainen and Päivi Salmesvuori, 177-193. New York: Palgrave Macmillan.

Kupari, Helena. 2016. Lifelong Religion as Habitus: Religious Practice among Displaced Karelian Orthodox Women in Finland. Leiden: Brill.

Kupari, Helena. 2014. “I was Both Lutheran and Orthodox': Evacuee Karelian Orthodox Women, Bidenominational Families, and the Making of Religion.” In Finnish Women Making Religion: Between Ancestors and Angels, edited by Terhi Utriainen and Päivi Salmesvuori, 143-160. New York: Palgrave Macmillan.

Laitila, Teuvo. 2006. "History of the Finnish Orthodox Church in the 20th Century." In A Short History of the Orthodox Church in Western Europe in the 20th Century, edited by Christine Chaillot, 157-176. Paris: InterOrthodox Dialogue.

Leming, Laura. 2007. "Sociological Explorations: What Is Religious Agency?" The Sociological Quarterly 48 (1): 73-92.

Levinas, Emmanuel. 1974. Autrement qu'être ou au-delà de l'essence. La Haye: Martinus Nijhoff.

Nguyen, Riina. 2007. "Converts-A Challenge and a Resource for the Church." In Orthodox Tradition and the 21st Century: Experiences of Past, Realities of Today, Challenges of Tomorrow, edited by Grant White and Teuvo Laitila, 123-127. Joensuu: University of Joensuu.

Ozorak, Elizabeth. 1996. “The Power, But Not the Glory: How Women Empower Themselves through Religion.” Journal for the Scientific Study of Religion 35 (1): 17-29.

Pollari, Pirjo. 2017. (Dis)empowering Assessment? Assessment as Experienced by Students in Their Upper Secondary School EFL Studies. Jyväskylä Studies in Humanities 329. Jyväskylä: University of Jyväskylä. 


\section{Pekka Metso et al.}

Sadati, Ahmad, Kamran Lankarani, Vahid Gharibi, Mahmood Fard, Najmeh Ebrahimzadeh, and Sedigeh Tahmasebi. 2015. "Religion as an Empowerment Context in the Narratives of Women with Breast Cancer." Journal of Religion and Health 54: 1068-1079. doi:10.1007/s10943-014-9907-2.

Statistics Finland. 2016. Population Structure 2015. "Appendix Table 6: Population by Religious Community in 2000 to 2015." www.stat.fi/til/vaerak/2015/01/ vaerak_2015_01_2016-09-23_tau_006_en.html.

Trzebiatowska, Marta, and Steve Bruce. 2012. Why Are Women More Religious than Men? Oxford: Oxford University Press.

Turner, Victor. 1969. The Ritual Process. Ithaca, NY: Cornell University Press.

Utriainen, Terhi, and Päivi Salmesvuori, eds. 2014. Finnish Women Making Religion: Between Ancestors and Angels. New York: Palgrave Macmillan.

Walter, Tony, and Grace Davie. 1998. "The Religiosity of Women in the Modern West.” British Journal of Sociology 49 (4): 293-306. 